\title{
ANALISIS INFORMASI CITRA ANTARA SEKUENS T2 FRFSE DENGAN T2 PROPELLERPADA PEMERIKSAAN MRI CERVIKAL POTONGAN AXIAL DENGAN PESAWAT MRI GE SIGNA 1,5 T
}

\section{ANALYSIS IMAGE INFORMATION BETWEEN T2 FRFSE SEQUENCES AND T2 PROPELLER SEQUENCES IN CERVICAL MRI EXAMINATION AXIAL SLICE WITH 1,5 T GE SIGNA MRI UNIT}

\author{
Sri Adhi Lukito ${ }^{1)}$, Darmini ${ }^{2)}$, Emi Murniati ${ }^{2}$ \\ ${ }^{1,2,3)}$ Health Polytechnics of Semarang-Indonesia \\ e-mail: adhi_lukito@yahoo.com
}

\begin{abstract}
Backgroud:research has been done on the difference of image information for T2 FRFSE sequences and T2PROPELLER in Radiology Installation of General Hospital Dr Moewardi. The aim of this study is to determine THE differences of the image information between T2 FRFSE sequences and T2PROPELLER sequences and determine the best sequence between T2 PROPELLER with T2 FRFSE in cervical MRI examination of Spine Axial Slice.

MethodsThis research is a quantitative study with experimental approach in Radiology Installation Dr. Moewardi Hospital. Data is collected on examination MRI Cervical in 15 patients, after a Cervical MRI scanning with sagittal slice T2 FRFSE sequences, and then performed scanning T2 PROPELLER sequences on Axial slice. Presented to the three doctors radiologist to assess. Once the image judged by the three respondents, the data analyse by using SPSS 17.0 with Wilcoxon test.

Results:the result showed obtained significance value 0,001 or $\mathrm{p}$ value $<0,05$ Which means that there are differences image information between T2 FRFSE sequences and T2 PROPELLER sequences. Sequens T2 PROPELLER better than sequens T2 FRFSE in MRI CervicalAxial slice.

Conclusion:Mean value of the same rank on the anatomy of the vertebral body and the soft tissue of the neck are 5.50 and 4.00 , while the mean rank differently on intraforamen structure is 6.5 , nerve root is 5.56 , so that the spinal cord was 6.15 T2 PROPELLER still better.
\end{abstract}

Keywords :T2 Propeller, T2 FRFSE, MRI Cervical, Image Information

\section{PENDAHULUAN}

Vertebra cervical adalah salah satu dari rangkaian tulang belakang yang merupakan ruas tulang bagian leher yang membentuk daerah tengkuk. Berfungsi sebagai pendukung dan penyangga tubuh dengan perantaraan tulang cakram intervertebralis yang memberikan kelenturan. Vertebra cervical tersusun dari tujuh ruas yang saling terkait melalui perantaraan tulang rawan cakram intervertebralis atau discus intervertebralis(Pearce 1999).

Protokol pada MRI cervical yang disarankan (Moeller 2007) adalah Sagital SE / FSE pembobotan T1, Sagital SE/FSE pembobotan T2 atau GE pembobotan T2*, Coronal SE/FSE pembobotan T1, Coronal SE/FSE pembobotan T2 atau GE pembobotan T2*, Axial/Oblique SE/FSE pembobotan T1, Axial/oblique SE/FSE pembobotan T2 atau GE pembobotan T2*, pada irisan Axial T2, disk tampak lebih terang seperti CSF, dan tulang maupun ligament tampak gelap. Dengan latar belakang yg terang, maka definisinya akan tampak jelas. Spinal cord dan akar saraf akan tampak lebih gelap sehingga tampak lebih jelas dan neural foramina akan tervisualisasi dengan baik karena CSF hiperintense (Fellner 2010).

Pemeriksaan MRI dengan berbagai kasus pada vertebrae cervical, dalam pemeriksaan yang relatif lama pasti ada terjadi pergerakan pada cervikal pasien baik ketika pasien menelan ludah, menghirup napas, peredaran darah dan pergerakan lain karena lamanya pemeriksaan, sehingga kemungkinan terjadinya motion artifak karena pergerakan tersebut. Seiring dengan kemajuan teknologi. Pada tahun 1999 dikembangkan metode perbaikan gambar meskipun mengalami pergerakan obyek yang disebut Periodically Rotated Overlapping Parallel Lines With Enhanched Recontruction (PROPELLER) variasi dari metode PROPELLER ini kemudian diadaptasi oleh beberapa vendor pabrikan pesawat MRI, dengan nama BLADE oleh siemens , PROPELLER oleh General Electrik, Multivane oleh Philips, RADAR oleh Hitachi dan JET oleh Toshiba (Siemens 2010).Periodically Rotated Overlapping Parallel Lines With Enhanched Recontruction (PROPELLER) adalah metode baru dalam proses pengumpulan dan rekonstruksi data untuk mengurangi artefak yang diakibatkan oleh rotasi dan pergerakan obyek. Metode tersebut memiliki kelebihan pada proses pengumpulan sampel dari data pada pusat $k$-space dan mendapatkan "arah" bawaan dari data atau informasi yang diperoleh (PIPE, 1999), Sedangkan T2 fast recovery fast spin echo (FRFSE) adalah modifikasi

Dari sekuen fast spin echo (FSE) standart dengan penambahan pulsa RF untuk recovery longitudinal magnetisasi setelah echo train dapat membuat enhance gambaran cairan saat TR diatur pendek, penggabungan sekuens ini dengan sekuens FSE standart menggunakan TR panjang dapat menampakan gambaran axial T2 weigthing 
image (David Cheng 2000). Kedua sekuens tersebut merupakan sekuen tambahan yang digunakan untuk menampakan gambaran yang di inginkan oleh radiolog.

\section{METODE}

Jenis penelitian ini adalah penelitian kuantitatif dengan pendekatan eksperimen. Populasi dalam penelitian ini adalah semua pemeriksaan MRI vertebra cervikal. Sampel terdiri dari 15 pasien pemeriksaan MRI vertebra Cervikal dengan sekuens T2 FRFSE dan T2 PROPELLER di Instalasi Radiologi RSUD DR Moewardi.

Variabel bebas dalam penelitian ini adalah sekuens T2 FRFSE dan sekuens T2 PROPELLER.Variabel terikat dalam penelitian ini adalah informasi citra, meliputi vertebral body, Nerve Root, spinal cord, struktur intraforamen dan soft tissue leher.Variabel terkontrol dalam penelitian ini adalah Time Repetition (TR), Time Echo (TE), slice thickness, interslice, matriks, dan Field of View (FOV), Nex .

Tahap pelaksanaan dimulai dengan pengaturan posisi pasien. Pasien diposisikan supine di atas meja pemeriksaan, bagian daerah cervikal diatur pada area cervikal coil. Posisi tubuh pasien diatur senyaman mungkin, dipastikan tidak ada rotasi, Mid Sagital Plane (MSP) tegak lurus meja pemeriksaan dan sejajar dengan lampu indikator longitudinal. Center point lampu kolimator dipusatkan pada regio C3- C4. Pasien dimasukkan ke dalam area magnet.

Tahap selanjutnya adalah Pengaturan sekuens dan parameter. Pemeriksaan dilakukan dengan sekuens T2 FRFSE dan sekuens T2 PROPELLER dilakukan pada obyek cervikal yang sama kepada lima belas pasien, dengan cara masing-masing pasien dilakukan scanning dengan sekuens T2 FRFSE kemudian dilanjutkan dengan scanning sekuens T2 PROPELLER. Pengaturan parameter yang dilakukan pada penelitian ini sudah merupakan program yang ada pada pesawat MRI GE signa1,5 Tesla yang menghasilkan kualitas citra terbaik. Parameter pada pesawat MRI GE signa 1,5 Tesla adalah sebagai berikut:

Tabel 1. Parameter pada pesawat MRI GE signa 1,5Tesla

\begin{tabular}{ccc} 
Parameter & $\begin{array}{c}\text { Sekuens T2 } \\
\text { FRFSE }\end{array}$ & $\begin{array}{c}\text { Sekuens T2 } \\
\text { PROPELLER }\end{array}$ \\
\hline TR & $3200 \mathrm{~ms}$ & $3200 \mathrm{~ms}$ \\
TE & $110 \mathrm{~ms}$ & $110 \mathrm{~ms}$ \\
FOV & $180 \mathrm{~mm}$ & $180 \mathrm{~mm}$ \\
Matrix & $128 \times 256$ & $128 \times 256$ \\
Slice Thickness & $3,5 \mathrm{~mm}$ & $3,5 \mathrm{~mm}$ \\
Interslice & $0,5 \mathrm{~mm}$ & $0,5 \mathrm{~mm}$ \\
NEX & 2 & 2 \\
\hline
\end{tabular}

Setelah memperoleh hasil gambaran MRI vertebra Cervikal potongan axialsekuens T2 FRFSE dan sekuens T2 PROPELLER, kemudian dipilih irisan axial C4/5 diburn pada CD/DVD.
HASIL

Setiap citra yang dihasilkan sekuens T2 FRFSE dan T2 PROPELLER diobservasi oleh 3 orang dokter radiologi dengan skor nilai $1-4$. Selanjutnya nilai skor masing-masing citra dari ketiga responden dirangkum dan dianalisis dengan uji statistik menggunakan metode Wilcoxon. Sebelum melakukan uji Wilcoxon terlebih dahulu melakukan uji kappa untuk menentukan nilai uji kappa tertinggi dari ke 3 responden tersebut dan dipilih salah satu responden untuk di analisis dengan uji Wilcoxon.

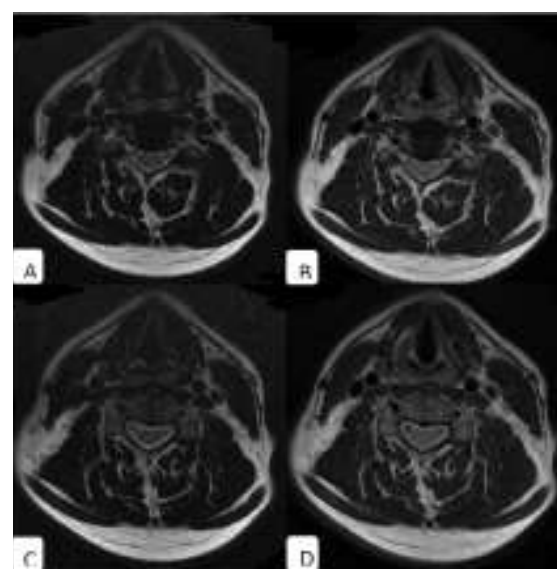

Gambar 1. Citra C4 T2 FRFSE (A), Citra C4 T2 PROPELLER (B), Citra C5 T2 FRFSE (C), CitraC5 T2 PROPELLER (D)

Tabel 2. Hasil penilaian informasi citra anatomi perkriteria pada sekuens T2 FRFSE

\begin{tabular}{|c|c|c|c|}
\hline \multirow{2}{*}{ NO } & \multicolumn{3}{|c|}{ Skor penilaian T2 FRFSE } \\
\hline & Anatomi & Total & Mean \\
\hline 1 & Struktur intraforamen & 41 & 2,73 \\
\hline 2 & Nerve Root & 45 & 3 \\
\hline 3 & Vertebra Body & 48 & 3,2 \\
\hline 4 & Spinal Cord & 43 & 2,86 \\
\hline 5 & Soft tissue pada Leher & 49 & 3,26 \\
\hline
\end{tabular}

Tabel 3. Hasil penilaian informasi citra anatomi perkriteria pada Sekuens T2 PROPELLER

\begin{tabular}{clcc}
\hline \multirow{2}{*}{ NO } & \multicolumn{3}{c}{ Skor penilaian T2 PROPELLER } \\
\cline { 2 - 4 } & \multicolumn{1}{c}{ Anatomi } & Total & Mean \\
\hline 1 & Struktur intraforamen & 55 & 3,63 \\
2 & Nerve Root & 54 & 3,6 \\
3 & Vertebra Body & 54 & 3,6 \\
4 & Spinal Cord & 55 & 3,63 \\
5 & Soft tissue pada Leher & 54 & 3,6 \\
\hline
\end{tabular}

Tabel 2 merupakan hasil penilaian yang didapatkan dari penilaian responden terhadap citra MRI Cervikal potongan axial perkriteria dengan 15 sampel pada sekuens T2 FRFSE didapatkan hasil mean dari anatomi struktur intraforamen yaitu 2,73. Anatomi Nerve Root yaitu 3. Anatomi Vertebra 
Body yaitu 3,2. Anatomi Spinal cord yaitu 2,86, Anatomi soft tissue pada Leher yaitu 3,26.

Tabel 3 merupakan hasil penilaian yang didapatkan dari penilaian responden terhadap citra MRI Brain potongan axial perkriteria dengan 15 sampel pada sekuens T2 PROPELLERdidapatkan hasil mean dari anatomi struktur intraforamen yaitu 3,63. Anatomi Nerve Root yaitu 3,6. Anatomi Vertebra Body yaitu 3,6. Anatomi Spinal cord yaitu 3,63, Anatomi soft tissue pada Leher yaitu 3,6

Berdasarkan nilai pada Tabel 6 dan 7 merupakan hasil penilaian perkriteria anatomi yang didapatkan dari check list yang dinilai oleh responden, jika dilihat pada sekuens kedua nilai mean untuk informasi anatomi secara keseluruhan sekuen T2 PROPELLER lebih baik dari pada T2 FRFSE.

Berdasarkan hasil uji statistik non parametrik diatas menunjukkan nilai signifikan $p$ value $=0.001$ atau $\mathrm{p}<0.05$, artinya Ho ditolak dan Ha diterima, menunjukkan adanya perbedaan yang signifikan pada informasi anatomi antara sekuens T2 FRFSE dengan sekuens T2 PROPELLER pada pemeriksaan MRI Cervikal potongan axial.

Tabel 4. Hasil penilaian informasi citra anatomi keseluruhan

\begin{tabular}{llcc}
\hline & \multicolumn{1}{c}{ Sekuen } & $p$-value & Keterangan \\
\hline 1 & T2 FRFSE & 0,001 & Ada beda \\
2 & T2 PROPELLER & & signifikan \\
\hline
\end{tabular}

Hasil penilaian berdasarkan masing-masing organ atau per kriteria anatomi diuji menggunakan uji Wilcoxon yang menghasilkan data sebagai berikut.

Tabel 5. Hasil Uji Wilcoxon informasi citra anatomi Struktur Intra foraminal antara sekuens T2 FRFSE dengan sekuens T2 PROPELLER

\begin{tabular}{lcc}
\multicolumn{1}{c}{ Informasi Citra } & $p$-value & Keterangan \\
\cline { 1 - 1 } Struktur Intra foraminal T2 & & Ada beda \\
FRFSE & 0,001 & $\begin{array}{l}\text { signifikan } \\
\text { Struktur Intra foraminal T2 } \\
\text { PROPELLER }\end{array}$ \\
\hline
\end{tabular}

Tabel 6 Hasil Uji Wilcoxon informasi citra anatomi Nerve Root antara sekuens T2 FRFSE dengan sekuens T2 PROPELLER

\begin{tabular}{cccc}
\hline & Informasi Citra & $\begin{array}{c}p \text { - } \\
\text { value }\end{array}$ & Keterangan \\
\hline 1 & Nerve Root T2 FRFSE & & $\begin{array}{l}\text { Ada beda } \\
\text { signifikan }\end{array}$ \\
2 & Nerve Root T2 PROPELLER & 0,013 & \\
\hline
\end{tabular}

Berdasarkan hasil uji statistik non parametrik wilcoxon menggunakan SPSS 17 pada tabel 5 dengan menyatakan bahwa tingkat kemaknaan (signifikan) $p$ value $=0.001$ $(p<0.05)$, hal ini menunjukkan adanya perbedaan yang signifikan pada Struktur Intra foraminal antara sekuens T2 FRFSE dengan sekuens T2 PROPELLER.

Berdasarkan analisis uji Wilcoxon menyatakan tingkat kemaknaan ( $\mathrm{p}$ value) pada Nerve Root adalah 0.013 ( $p<$
0.05). Hal ini menunjukkan adanya perbedaan yang signifikan antara sekuens T2 FRFSE dengan sekuens T2 PROPELLER potongan axial pada Nerve Root. Berikut merupakan hasil uji Wilcoxon pada citra MRI Cervikal potongan axial pada anatomi Vertebra Body.

Tabel 7. Hasil Uji Wilcoxon informasi citra anatomi Vertebra Body antara sekuens T2 FRFSE dengan sekuens T2 PROPELLER

\begin{tabular}{clcc}
\hline \multicolumn{2}{c}{ Informasi Citra } & $p$-value & Keterangan \\
\cline { 1 - 2 } 2 & $\begin{array}{l}\text { Vertebra Body T2 FRFSE } \\
\text { Vertebra Body T2 } \\
\text { PROPELLER }\end{array}$ & 0,058 & $\begin{array}{c}\text { Tida ada } \\
\text { beda }\end{array}$ \\
\hline
\end{tabular}

Analisis uji Wilcoxon menunjukkan tidak adanya perbedaan antara sekuens T2 FRFSE dengan sekuens T2 PROPELLER pada potongan axial pada Vertebra Body, ditunjukkan dengan besarnya nilai $p$ value $>0.05$, yaitu $p=$ 0.058 .

Tabel 8. Hasil Uji Wilcoxon informasi citra anatomi Spinal cord antara sekuens T2 FRFSE dengan sekuens T2 PROPELLER

\begin{tabular}{|c|c|c|c|}
\hline & Informasi Citra & $p$-value & keterangan \\
\hline 1 & $\begin{array}{c}\text { Soft tissue pada Leher T2 } \\
\text { FRFSE }\end{array}$ & \multirow{2}{*}{0,008} & \multirow[b]{2}{*}{$\begin{array}{l}\text { Ada beda } \\
\text { signifikan }\end{array}$} \\
\hline 2 & $\begin{array}{c}\text { Soft tissue pada Leher T2 } \\
\text { PROPELLER }\end{array}$ & & \\
\hline
\end{tabular}

Tabel 9. Hasil Uji Wilcoxon informasi citra anatomi Soft tissue pada Leher antara sekuens T2 FRFSE dengan sekuens T2 PROPELLER

\begin{tabular}{cccc}
\hline & Informasi Citra & p-value & Keterangan \\
\hline 1 & Soft tissue pada Leher T2 & & \\
& FRFSE & 0,059 & Tidak ada beda \\
2 & $\begin{array}{c}\text { Soft tissue pada Leher T2 } \\
\text { PROPELLER }\end{array}$ & & \\
\hline
\end{tabular}

Tabel 10. Hasil Mean Rank Uji Statistik Wilcoxon pada Informasi citra Anatomi antara sekuens T2 FRFSE dengan sekuens T2 PROPELLER

\begin{tabular}{|c|c|c|c|c|}
\hline & Kriteria & Sekuen & $\begin{array}{c}\text { Mean } \\
\text { rank }\end{array}$ & keterangan \\
\hline \multirow[t]{3}{*}{1} & Struktur & T2 FRFSE & 0,00 & \multirow{3}{*}{$\begin{array}{l}\text { Ada beda } \\
\text { signifikan }\end{array}$} \\
\hline & Intraforamen & $\mathrm{T} 2$ & & \\
\hline & & PROPELLER & 6,50 & \\
\hline \multirow[t]{3}{*}{2} & Nerve Root & T2 FRFSE & 5,00 & \multirow{3}{*}{$\begin{array}{l}\text { Ada beda } \\
\text { signifikan }\end{array}$} \\
\hline & & $\mathrm{T} 2$ & & \\
\hline & & PROPELLER & 5,56 & \\
\hline \multirow[t]{3}{*}{3} & Vertebra Body & T2 FRFSE & 5,50 & \multirow{3}{*}{$\begin{array}{c}\text { Tidak ada } \\
\text { beda }\end{array}$} \\
\hline & & $\mathrm{T} 2$ & 550 & \\
\hline & & PROPELLER & 5,50 & \\
\hline \multirow[t]{3}{*}{4} & Spinal Cord & T2 FRFSE & 4,50 & \multirow{3}{*}{$\begin{array}{l}\text { Ada beda } \\
\text { signifikan }\end{array}$} \\
\hline & & $\mathrm{T} 2$ & & \\
\hline & & PROPELLER & 6,15 & \\
\hline \multirow[t]{3}{*}{5} & $\begin{array}{l}\text { Soft tissue } \\
\text { pada Leher }\end{array}$ & T2 FRFSE & 4,00 & \multirow[t]{3}{*}{$\begin{array}{c}\text { Tidak ada } \\
\text { beda }\end{array}$} \\
\hline & & $\mathrm{T} 2$ & 4,00 & \\
\hline & & PROPELLER & 4,00 & \\
\hline
\end{tabular}


Penilaian informasi citra pada tabel 8 mengenai Spinal cord dengan uji Wilcoxon menunjukkan bahwa ada perbedaan yang signifikan antara sekuens T2 FRFSE dengan sekuens T2 PROPELLER pada potongan axial. Hal ini ditunjukkan pada $p$ value $=0.008(p<0,05)$.

Penilaian informasi citra mengenai soft tissue Leher dengan uji Wilcoxon menunjukkan bahwa tidak ada perbedaan antara sekuens T2 FRFSE dengan sekuens T2 PROPELLER pada potongan axial. Hal ini ditunjukkan pada $p$ value $=0.059$ $(p>0,05)$.

Penelitian mengenai perbedaan informasi citra antara sekuens T2 FRFSE dengan sekuens T2 PROPELLER pada pemeriksaan MRI Cervikal dianalisis dengan melihat mean rank untuk mengetahui sekuens yang lebih baik dalam menghasilkan informasi citra anatomi. Nilai mean rank pada uji statistik non parametrik Wilcoxon dapat dilihat pada tabel 10 .

Hasil mean rank uji Wilcoxon pada tabel 10 menunjukan bahwa sekuens T2 PROPELLER memiliki nilai yang lebih tinggi pada kriteria anatomi struktur intraforamen, nerve root dan Spinal cord sedangkan pada nilai mean rank anatomi Vertebra Body dan soft tissue leher sama.

\section{DISKUSI}

Berdasarkan hasil uji statistik non parametrik menunjukkan nilai signifikan $p$ value $=0.0001$ atau $\mathrm{p}<0.05$, artinya Ho ditolak dan $\mathrm{Ha}$ diterima, menunjukkan adanya perbedaan yang signifikan pada informasi citra antara sekuens T2 FRFSE dengan T2 PROPELLER pada pemeriksaan MRI Cervikal potongan axial. Hasil uji Wilcoxon pada informasi citra per kriteria anatomi juga terdapat perbedaan secara signifikan yaitu pada 3 kriteria anatomi struktur intraforamen, Nerve Root dan Spinal Cord, sedangkan untuk 2 kriteria anatomi relatif sama pada Vertebra Body dan soft tissue pada leher.

T2 FRFSE memiliki kelebihan untuk menampakan detail gambaran patologis yang bagus, Pada sekuens T2 FRFSE selain untuk mendapatkan gambaran patologis, juga terjadi enhance ment pada jaringan yang sehat. Hal ini disebabkan pada sekuens T2 FRFSE, lemak tampak hiperintens dan detail gambar lebih bagus, tetapi memiliki kekurangan berupa mengurangi slice coverage, sehingga informasi yang didapat tidak maksimal, terjadinya Blurring pada citra imajing, tidak sensitif terhadap Pendarahan (hemorage) (Ai-Jun ren, 2012).T2 PROPELLER akan memakan waktu scaning yang relative lebih lama. PROPELLER MRI telah diterapkan dalam studi jantung, brain, spinal cord, abdomen, cartilage, dan liver. Secara umum, itu menunjukkan bahwa teknik ini yang tersedia hasil yang lebih unggul di daerah dengan inhomogeneities dan pada obyek yang bergerak menjadi lebih signifikan (Magnreson, 2009).

Sedangkan untuk parameter T2 PROPELLER juga menggunakan TR yang panjang dan TE yang panjang tetapi pada T2 PROPELLER menggunakan acquisition mode non cartesian parameter inilah yang berpengaruh terhadap mengontrol motion. Non cartesian adalah teknik pengambilan gambar dengan Pusat k-space ( yang berisi amplitudo sinyal tertinggi dan memberikan kontribusi yang paling baik untuk kontras gambar ) yang oversample, yang berarti bahwa sinyal ke noise dan kontras ke noise akan tinggi, oversample tersebut akan itu menunjukkan bahwa teknik ini memberikan hasil yang lebih unggul di daerah dengan inhomogeneities dan pada obyek yang bergerak menjadi lebih signifikan (Magnreson, 2009).

Jika dilihat dari waktu akuisisi sekuens T2 FRFSE lebih cepat yaitu 3:18 menit, sedangkan sekuens T2 PROPELLER sepuluh detik lebih lama yaitu 03:34. teknik ini yang tersedia hasil yang lebih unggul di daerah dengan inhomogeneities dan pada obyek yang bergerak menjadi lebih signifikan dan waktu yang dibutuhkan relatif tidak terlalu lama selisihnya dibandingkan dengan T2 FRFSE. Kedua sekuens tersebut memiliki kelebihan dan kekurangannya masing-masing.

Penilaian dari keseluruhan informasi anatomi dilakukan berdasarkan subjektifitas dari responden yaitu radiolog yang telah berpengalaman minimal 5 tahun dalam membaca citra MRI.

Jika dilihat dari hasil uji Wilcoxon untuk keseluruhan anatomi maupun perkriteria pada pengujian Statistik Non Parametrik Wilcoxon didapatkan hasil bahwa sekuens PROPELLER lebih baik dalam menampakkan informasi anatomi daripada sekuens T2 FRFSE. Sedangkan dilihat dari mean rank ada 3 kriteria anatomi T2 PROPELLER lebih baik, 2 kriteria T2 FRFSE dan T2 PROPELLER sama baik. Sehingga jika melihat hasil mean rank tidak seluruhnya ada perbedaan. Hasil mean rank uji Wilcoxon pada tabel 12 menunjukan bahwa sekuens T2 PROPELLER memiliki nilai yang lebih tinggi pada kriteria anatomi struktur intraforamen, nerve root dan Spinal cord sedangkan pada nilai mean rank anatomi Vertebra Body dan soft tissue leher sama. Setelah di konsultasikan dengan 3 responden untuk beberapa klinis memang dibutuhkan kedua sekuens tersebut, dan ada responden yang hanya menggunakan salah satu dari kedua sekuens tersebut karena alasan pasien yang kurang kooperatif sehingga scaning MRI harus lebih cepat tanpa menghilangkan informasi yang dihasilkan. Misal untuk klinis pasien dengan kelainan degeneratif, stenosis, NMO (neuro myelitic optica), kedua sekuens tersebut bagus digunakan.

\section{SIMPULAN}

Berdasarkan hasil penelitian perbedaan informasi citra antara sekuens T2 FRFSE dengan T2 Propeller pada pemeriksaan MRI cervikal potongan axial dengan pesawat MRI GE 1,5 T yang dilakukan di Instalasi Radiologi RS Dr Moewardi didapatkan kesimpulan sebagai berikut.

Terdapat perbedaan citra secara keseluruhan yang signifikan antara sekuens T2 FRFSE dan sekuens T2 PROPELLER pada pemeriksaan MRI Cervikal potongan axial karena memiliki $\mathrm{p}$ value sebesar $0,001(\mathrm{p}<0,05)$ dengan secara umum, sekuens T2 PROPELLER menghasilkan informasi citra yang lebih baik dibandingkan dengan sekuens T2 FRFSE.

Sekuens T2 PROPELLER lebih baik dibandingkan T2 FRFSE sesuai dengan hasil uji beda keduanya dilihat dari mean rank ada 3 kriteria anatomi T2 PROPELLER lebih baik, 
2 kriteria T2 FRFSE dan T2 PROPELLER sama baik. Mean rank yang sama yaitu pada anatomi Vertebra Body dan soft tissue leher yaitu 5,50 dan 4,00, sedangkan untuk mean rank struktur intraforamen adalah 6,5, nerve root adalah 5,56, Spinal cord adalah 6,15 sehingga T2 PROPELLER masih lebih bagus.

\section{DAFTAR PUSTAKA}

Ai-Jun, Ren. 2012. MR Imaging of the Spine at 3.0T with T2-Weighted IDEAL Fast Recovery Fast Spin-Echo Technique. Department of Radiology, Navy General Hospital of PLA : Beijing.

David, Cheng. 2000. Comparison of Fast Recovery Fast spin echo and Conventional Fast spin echo for T2 weighted imaging of the Prostate Gland. Brigham and Women s Hospital, Boston, MX, GE Medical Systems, Fovt Lee, NJ.

Erickson, H. 2007. PROPELLER MRI visualizes detailed pathology of hippocampal sclerosis; Department of Clinical and Experimental Epilepsy. Institute of Neurology : UCL, Queen Square, Box 29, London WC1N 3BG, United Kingdom.

Fellner. 2010. BLADE in sagital T2 weighted imaging of the cervikal spine. AJNR university medical center Regensburg : Germany.

Magnreson. 2010. Motion correction in Propeller an Turboprop MRI Chicago National Institue of Health.

Moeller. 2003. MRI parameters and positioning head neck and chest. C.V. thieme : Stutgart, Germany.

Pearce, C Evelyn. 1999. Anatomi untuk paramedis. Gramedia : Jakarta.

Pipe. 1999. Motion correction with PROPELLER MRI :Application to Head Motion and Free breathing Cardiac imaging. Chicago National Institue of Health.

Siemens. 2010. Blade Siemens healthcare aven to australia

Sugiyono. 2010. Metode Penelitian Kuantitatif Kualitatif dan R\&D. Alfabeta, Bandung.

Snell, Richard S. 2006. Anatomi Klinik untuk Mahasiswa Kedokteran; alih bahasa Liliana Sugiharto, Ed 6. ECG : Jakarta.

Vertinksy. 2007. Cutting Edge Imaging of THE Spine. Department of Radiology Medical University of Graz Auenbruggerplatz 9, 8036 Graz : Austria.

Weckbach, S. 2008. Magnetic resonance imaging of the cervical spine: comparison of 2D T2-weighted turbo spin echo, 2D T2*weighted gradient recalled echo and 3D T2-weighted variable flip-angle turbo spin echo sequences. Department of Clinical Radiology, University Hospital Mannheim, Medical : Germany.

Westbrook, Catherine. 1999. Handbook of MRI Technique. Blackwell Science Ltd : United Kingdom.

Westbrook, C. and Kaunt, C. 1999. MRI in Practise. Blackwell Science Ltd. : United Kingdom

Westbrook, Catherine. 2008. Handbook of MRI Technique, vol 3. Blackwell Science Ltd. : United Kingdom. 